
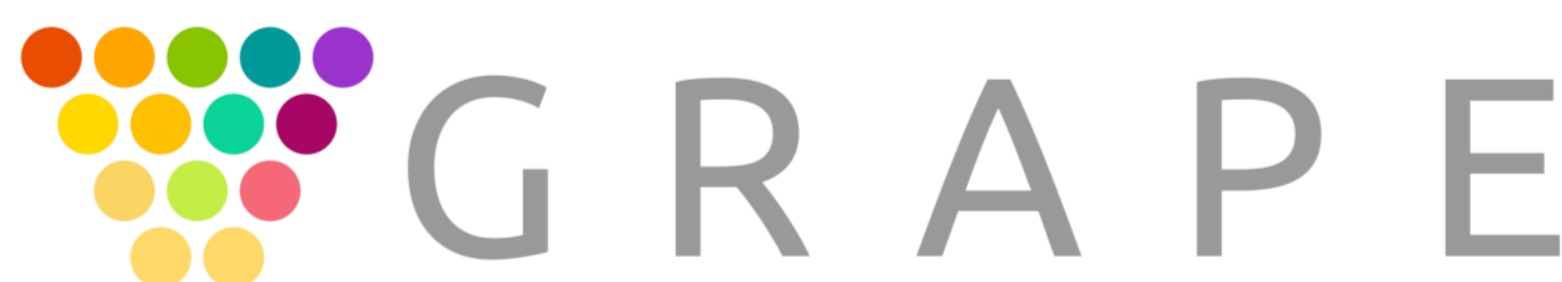

Group for Research in APplied Economics

GRAPE Working Paper \# 15

Upstreamness of employment and global financial crisis in Poland: the role of position in the global value chains Jan Hagemejer, Joanna Tyrowicz

Foundation of Admirers and Mavens of Economics Group for Research in Applied Economics 


\title{
Upstreamness of employment and global financial crisis in Poland: the role of position in the global value chains
}

\author{
Jan Hagemejer \\ FAME|GRAPE \\ University of Warsaw \\ National Bank of Poland
}

\author{
Joanna Tyrowicz \\ FAME|GRAPE \\ University of Warsaw
}

\begin{abstract}
The emergence of global value chains leads to fragmentation of the production processes and reallocation of those processes across countries. With increasing number of production stages, the manufacturing process is located increasingly further away from the consumer. Literature suggests that fragmentation of production increases the international transmission of shocks. The global financial crisis is believed to lead to consolidation and shortening of global value chains and amplification of demand shocks along the global value chains, the so-called bullwhip effect. In this paper we study the effects of global financial crisis on employment, focusing specifically on the role of the distance from final demand (upstreamness) in this adjustment. We find that upstreamness matters for both labor demand and adjustment in employment during the periods of crisis, but this relationship is heterogeneous across countries. While the reaction to the crisis is indeed amplified further away from final demand, contrary to our expectations it is mostly channeled through lower job creation rates rather than faster job destruction. Moreover, the adverse effects of the crisis are lower in foreign firms, this difference does not depend on the distance from final demand.
\end{abstract}

Keywords:

upstreamness, global value chains, employment, global financial crisis

JEL Classification

F16, F62, F66

Corresponding author

Jan Hagemejer, j.hagemejer@uw.edu.pl

Acknowledgements

We would like to thank Peter Szewczyk and Lucas van der Velde for wonderful research assistance. The work on this project was facilitated by the Suntory fund and by earlier research by Jan Hagemejer on the role of global value chains (grant from national Science Center, UMO2013/09/D/HS4/01519). Authors would like to thank the participants of Hitotsubashi University and WIIW workshop in Vienna for valuable comments on earlier versions of this research. The remaining mistakes are the sole responsibility of the Authors.

Published by: $\quad$ FAME | GRAPE

ISSN: $\quad$ 2544-2473

(c) with the authors, 2017

W I grape.org.pl

E | grape@grape.org.pl

$\pi \quad$ GRAPE_ORG

FB I GRAPE.ORG

PH ～～+48799012202 


\section{Introduction}

Towards the end of $20^{\text {th }}$ century, with increased international trade came about the processes of production fragmentation across borders within the value chain (Hummels, Ishii \& Yi, 2001). However, as documented by Fally (2011) fragmentation itself remained roughly constant until the end of 1990s. It was the improvement in communication technologies which allowed for substantial innovation in management: a final product is barely ever produced in a single location and the number of stages of production has increased substantially since 2000 (Baldwin, 2011; Baldwin \& Venables, 2013; Baldwin \& Evenett, 2015). As a result, the globalization implied not only more trade in goods, but also more flow of the managerial and technological know-how. Many countries could industrialize much faster by joining global value chains rather than building their own (Baldwin \& Robert-Nicoud, 2014). Also, within the advanced countries, higher fragmentation of production improves long-run export performance (Guerrieri \& Caffarelli, 2012). Danninger \& Joutz (2007) find that fragmenting production chains was a key determinant of Germany's improved export performance. Bas and Strauss-Kahn (2011) analyze the firm level data on French exporters and conclude that an increase in the set of imported input varieties increased significantly the number of exported varieties. All these findings are consistent with the underlying theory: firms, which can fragment their production stages and/or delocalize tasks because of lower communication and coordination costs, benefit from lower production costs and increase the efficiency as well as international competitiveness, hence their export performance (Baldwin, 2006).

Against this general background of global adjustments in trade and production structures that enhance the strength of economic links between countries, global financial crisis has marked an unprecedented trade collapse. For the first four quarters after the collapse of Lehman Brothers (2008Q1 - 2009Q1) world trade fell by about 15\% in real terms, i.e. roughly 4 times as much as the fall in global GDP. The fall was concentrated especially among global major traders, but affected virtually all countries of the world and all types of products. Reviewing substantial literature in the field, Bems et al (2013) argue the main driver of this exceptional fall in global trade was the collapse in aggregate expenditure, concentrated on trade-intensive durable goods. The second wave of decline, which deepened the collapse of trade in subsequent the initial shock, was the adjustment in inventories and negative shocks to credit supply - relevant particularly for global value chains not integrated by ownership.

Despite relatively short time since the event, the literature has given substantial attention to the consequences of the great trade collapse in the context of the global value chains. In 2010 The World Bank published a book analyzing the changes in the global value chains in the aftermath of the global financial crisis. The focus of the analyses was on reallocation of the production processes between countries. Milberg \& Winkler (2010) argue that 
asymmetrical recovery of trade volumes lead to consolidation of the global value chains, with consolidation effects more prevalent in buyer-led chains. Some sectors experienced substantial consolidation of the global value chains (Sturegon \& Kawakami, 2010), while in some others there was substantial reshuffling of production stages between the countries (Sturgeon \& Biesebroeck, 2010).

As suggested by Bems et al (2013), the so-called bullwhip effect, played an important role. This effect involves and amplified reaction in inventories to adverse shocks in demand and it is felt substantially stronger by firms from intermediate industries (Altomonte et al, 2012) with a faster rebound in output and production within ownership chains than for firms operating at arm's length with the buyers. Zavacka (2012) shows that the volatility in intermediate goods demand has sometimes been too substantial for the trade link to survive, often leading to a permanent collapse in production of a given intermediate product.

Despite an immediate relationship between the trade collapse and employment, so far much less research has analyzed this particular aspect of economic adjustment at periods of crisis. Sinha (2010) finds that more globally linked sectors in developing countries often resorted to suppressing wages and increasing the extent of informality to accommodate these amplified shocks. Hurst et al. (2010) demonstrate that in Asia these adjustments were disproportionately concentrated among temporary and migrant workers. These analyses focused on developing countries and thus may be less informative about the path of adjustment in advanced and catching up transition economies. Timmer et al. (2010) show that advanced economies increasingly specialize within the global value chains in activities carried out by high-skilled workers, which is likely to mitigate the employment effects. On the other hand, a large share of internationalization in the catching up transition economies consisted of processing trade. While this helped to maintain a relatively high share of manufacturing in employment and value added, at the times of the global financial crisis it might have had acute consequences for employment.

Our analysis aims to address this empirical question. On the one hand, one should expect from theory that higher upstreamness is associated with higher demand for labor and more resistance to adverse product demand shocks. On the other hand, it is likely that the distance from the final demand may affect upstream firms nonlinearly. Hence, it could be the case that events such as great trade collapse spur negative employment shocks: directly and through amplification of the result on inventories associated with the bullwhip effect. Following recent methodological contribution by Antras et al. (2012, 2013) we use the measures of upstreamness for Poland and other countries in Central and Eastern Europe computed by Hagemejer and Ghodsi (2016). Using firm-level data we estimate the overall effect of upstreamness on labor demand and its features. We also analyze the specific adjustments in the course of the global financial crisis, with a special 
emphasis on the possibly diversified position in the global value chains. We present comparative evidence for other countries of Central and Eastern Europe as well.

We find that transition economies of Central and Eastern Europe do not exhibit strong bullwhip effects. While demand for labor changed in the period of global financial crisis, this change was only to some extent affected by the position in the global value chain and only in few selected cases foreign owned firms responded differently in terms of employment than domestic firms.

Our study is structured as follows. In the next section we describe data and identification strategy. After descriptive analysis of the overall trends in upstreamness, we move to econometric analysis of various measures of employment. We analyze level the effects as well as (net) job creation and destruction at the times of global financial crisis and outside this period.

\section{Data and empirical strategy}

This study uses firm-level data from Bureau van Dijk also known as Amadeus database, and widely used in firm-level trade literature (e.g. Altomonte et al, 2013; Egger et al, 2015; Bloom et al, 2016). This data is distributed in editions, with each edition covering up to 10 years of firms' history. Clearly, not each firm in a given edition of Amadeus data has existed for up to 10 years. Effectively, the median duration of a panel for most countries in Amadeus is about 4 to 6 years. When combined, subsequent editions of Amadeus may yield longer firm-level panels. In this study we combine editions from 2004, 2008, 2010 and 2012, thus obtaining nominal data coverage from 1997 to 2011. However, availability for the countries of interest was low in the 1990s and increased only gradually, therefore the bulk of the data comes from 2000-2011. Thanks to the identifier common across the different revisions of Amadeus, we are able to track individual firms over time.

The number of firms in each edition of Amadeus depends on a year and country. Recent years are far more comprehensive than data from the past, while larger countries are characterized by a larger number of records than other. For example, in total, a 2014 edition of Amadeus comprises data on 18.3 million firms from 44 countries, but a 2004 edition comprises data on only 6.8 million firms and from only 38 countries.

Data in Amadeus usually come from national information providers and are based on registry courts. Hence, data coverage by size differs between countries and so does the availability of relevant economic information. We follow the procedure by Kalemli-Ozcan et. al (2015). After cleaning the incorrect and missing information, the final database contains information from the balance sheets and the income statements, in particular the employment, investment rate, output and cost of employment, together with the NACE

codes of the main activity (revision 1 and revision 2 where applicable). In addition, foreign ownership is identified in the data. 
We merge the resulting firm-level database with sector-level measures computed on the basis of the World Input Output Database rev. 2013 for the same period (see Timmer et al, 2015). The merging is performed using the WIOD aggregation of NACE rev. 1 (2 digit categories) and required matching of NACE rev.1 and NACE rev. 2 codes for post-2008 Amadeus data.

Table 9.1 describes the overall final sample size and gives descriptive statistics for Poland in particular and CEE economies overall. Despite well-known shortcomings of the Amadeus data, the final sample remains large and appears to replicate the main features of these economies in terms of production structure as well as firm size.

\section{Trends in internationalization}

The process of opening up of the former socialist economies in Central and Eastern Europe (CEE) that has been ongoing since the beginning of the 1990s manifested itself in the increased importance of international trade as well as an increased participation of foreign capital in the ownership of enterprises (Figure 9.1). In most of the analyzed countries roughly $5 \%$ to $15 \%$ of firms in the Amadeus database are foreign owned. However, in terms of the value added produced, the foreign firms in all analyzed economies generated over $20 \%$ of the value added of all enterprises in the Amadeus database.

Ownership integration is not the only mode of internationalization in the region. There is significant increase in the exports share of output as well as of import share in costs (Figure 9.2). The latter variable amounted to roughly $12 \%$ of the value of gross output in most CEE economies by 2011. Although intermediates constituted a large part of exports already in 1997, this share continued to grow in 2000s. The upstreamness of exports (the distance from final demand) has also increased over time both due to the overall increases of fragmentation in the world production and the greater specialization of CEE economies in intermediate goods. Hagemejer (2015) reports that vertical specialization, as defined by Wang et. al (2013) has increased and by 2011 reached as much as $40 \%$ in in Czech Republic and Hungary. In Poland for example, vertical specialization increased from 15\% to almost $30 \%$.

Employment share of internationalized firms (either by foreign ownership or by foreign sales) continued to increase over the entire analyzed period, see Figure 1. While the growth rate was not monotonous, it appears to have driven increasingly the employment dynamics in the analyzed countries. For Poland, evidence from other studies shows that this increase was not only pronounced, but also accompanied by compensation policy of systematic and relatively high wage growth. NBP (2015) demonstrates that although foreign firms are only $10 \%$ of $9+$ enterprises, they constitute for more than $20 \%$ of employment and for over $60 \%$ of payroll growth. 


\section{Empirical strategy}

Our measure of upstreamness is drawn directly from Antras et al. $(2012,2013)$. We use the measures computed by Hagemejer and Ghodsi (2016). They have used the World Input-Output Database available for 1997-2012 to compute global position at the sectorlevel for all countries in the sample (Timmer et al, 2015). The definition by Antras et al. (2012) is as follows:

$$
\mathrm{u}_{\mathrm{i}}=1 \cdot \frac{X_{i}}{Y_{i}}+2 \cdot \frac{\sum_{i j}^{N} z_{i j} X_{j}}{Y_{i}}+3 \cdot \frac{\sum_{k=1}^{N} \sum_{i j}^{N} z_{i j} z_{j k} X_{i}}{Y_{i}}+\cdots
$$

where $Y_{i}$ is the gross output of sector $i$ and $X_{i}$ is the final demand for goods from sector $i$ where $z_{i j}$ is the input-output coefficient of the intermediate use of goods from sector $i$ used in the production of sector $j$. Therefore the measure weighs the of the stage: 1 if output is used in final demand, 2 if output is used in production of goods that are subsequently used in final demand, 3 if output is used in production of goods that are used further in production of intermediate goods that are then used in satisfying final demand and so on. This measure is therefore bounded below by 1 (for details and comparative overview of CEE economies see Hagemejer \& Ghodsi, 2016). In our regressions we use the inverse of upstreamness. This measure is between 0 and 1 , where 1 means very downstream and 0 very upstream.

We estimate a labor demand function. We are not particularly interested in the determination of the level of employment, our dependent variable is the growth of employment at the firm level. All regressions control for the growth rate of output at the firm level, investment rate and the change in labor costs.

First, we analyze the relationship between level of employment and the inverse of upstreamness. Naturally, the coefficients here may be flawed with endogeneity. However, unless any given firm has a globally dominant position, upstreamness of the sector is not likely to be directly influenced by the firm-level decision, at least not contemporaneously. We also cluster standard errors at sector level to avoid inflating the statistical significance. Despite these precautions, we are aware that this specification does not favor direct causal interpretations. Moreover, our equations account for a change in employment, as well as (net) job creation and job destruction. Given innate first differencing, these specifications are free of the bias that would stem from firm-specific time-invariant unobservable heterogeneity.

In all regressions we are particularly interested in the potentially specific character of the nexus between position in the global value chains and employment decisions. Hence, in addition to the employment measure we also introduce an interaction between this variable and a dummy for the global financial crisis, which takes the value of 1 in the years 2008 and 2009 and equals 0 otherwise. 
In addition to controlling for upstreamness, we also include other indicators of globalization. First, we include sector-level exports as a share of total output. While this is clearly a firm-level decision if engage in exports at all, this indicator captures changes in foreign demand and allows to control for exposure to foreign demand shocks. Second, we also control for foreign ownership. Relying on the identification of ownership in the Amadeus data we code the firm to be foreign owned if it has any share of foreign ownership. In the analyzed period Amadeus does not report actual share of ownership, only the fact that among owners or shareholders there is some non-domestic legal or physical entity. Hence, this measure is likely to overstate the foreign ownership and thus the estimated coefficient is likely to be the lower bound. Third, given the growing relevance of the processing trade, we also control for the intermediate imports. Fourth, in order to control for involvement of exports in the global value chains, we include the sectoral share of intermediate goods in exports. All of the above variables are computed using the WIOD database.

Our employment growth regressions are estimated by OLS. The job creation and job destruction regressions are estimated using a Tobit model, due to a natural truncation of those variables. One has also to keep in mind that job destruction is measured as a growth rate of employment truncated below zero, i.e. an increase in the JD variable means lower job destruction. In other words, the interpretation of a positive coefficient in both job creation and job destruction equations is that an increase in the variable under consideration leads to higher employment growth, other things equal.

\section{Results}

We first present the results for Poland - the largest economy of the CEE region. Subsequently, we test to what extent the conclusions for Poland are in fact universal for the region. Results of the baseline set of regressions are presented in Table 9.2. Naturally, the overall growth rate of employment, the rate of job creation (JC) and the (negative of the) rate of job destruction (JD) are negatively related to the change in the unit labor costs and positively related to the change in output. Investment often replaces capital with labor, which has negative effect on employment. This is a general tendency, observed also in the other countries of the region.

Globalization seems to affect job creation and job destruction rates in a different ways while export shares are negatively related to job creation, job destruction is slower in the export oriented sectors. Similar pattern applies to the involvement of a sector in the imports of intermediate goods. One can also see that the share of intermediate exports in overall exports is positively related to the job creation rate.

Analyzing the role of global value chains and how they intertwine with the global crises on the example of the recent financial crisis reveals that not many patterns identified 
previously in developing economies are present in CEECs. In the interest of brevity, we report results for Poland in Table 9.2 and estimates on the coefficients of interest are also pictured in Figure $\mathbf{9 . 3}$ for all analyzed countries. ${ }^{1}$ Naturally, global financial crisis was associated with less job creation and to some extent more job destruction. Firm level growth of employment was lower by roughly 4 pp. in Poland over 2009-2010. It also appears that the point estimate is somewhat higher for job creation than for job destruction. Hence, while the global financial crisis has triggered some recession-type cleansing effects even in countries which did not experience recession, like Poland, it seems that most of the employment effects concerned a freeze on job creation. Regressions for the other 6 New Member States of the European Union (Bulgaria, Czech Republic, Hungary, Poland, Romania, Slovakia and Slovenia) shows a great deal of heterogeneity in the behavior of job creation and job destruction during the crisis years. In most of the analyzed economies, the response of job creation was much larger than that of Poland, except Slovenia. The highest employment reaction to the crisis was found in Romania and Slovakia.

The overall employment growth is dependent on the position of the sector in the production chain (faster growth of employment occurs further away from final demand), it seems mostly to be driven by the differences in job destruction rates. In manufacturing, faster employment growth occurred further away from the final demand. This effect is mostly due to the difference in job creation rates along the production chain as for the job destruction the $1 / \mathrm{U}$ variable is not statistically significant and therefore the evidence of the bullwhip effect is limited. At the same time, foreign ownership is in general related to less job destruction and (in manufacturing) more job creation.

During the global financial crisis, upstreamness matters for the labor demand, both in levels and in changes. The coefficient on the interaction between $1 / \mathrm{U}$ and global financial crisis dummy is positive for job creation, indicating faster job creation and less job destruction closer to final demand. This effect is also visible albeit smaller for job creation in manufacturing. These effects do not seem to be affected by foreign ownership both as far as the financial crisis effect is concerned as well as in the case of interaction with the $1 / \mathrm{U}$.

These patterns are far from universal in the region, as depicted by a dispersion of estimates in both panels of Figure 9.3. While the patterns of job creation were somewhat similar across all the countries (although the size of the effect varied considerably), job destruction patterns were very heterogenous. Unlike in Poland, in Czech Republic, Hungary and Slovenia, job destruction was milder closer to final demand. As far as the behavior of job destruction during the global financial crisis along the value chain is

\footnotetext{
${ }^{1}$ Detailed logs available upon request.
} 
concerned, the effects of lower job destruction closer to final demand were visible also in Czech Republic, Slovakia and Slovenia. In all of the countries of the region, the role of foreign ownership in GVC departs from what was suggested by earlier literature on developing countries. In fact, foreign owned firms typically behave no differently than domestic firms.

\section{Conclusions}

In the aftermath of the global financial crisis, substantial literature has emerged analyzing the role of global value in spreading the crisis across countries. Through reduced downstream demand in advanced economies, amplified by the overshooting in the inventories decisions (the so-called bullwhip effects), the global financial crisis disproportionately strongly labor markets in developing economies. Our paper analyzes this process for the economies of Central and Eastern Europe. Being closely integrated with many advanced market economies, these countries are an interesting case to study.

We focus on labor demand and find that the reaction to global financial crisis was heterogeneous. While involvement in the global value chains in general and the upstreamness in particular matter for employment level, as well as job creation and job destruction in net terms, there appears to be substantial dispersion across countries in how these processes influence employment decisions. In particular, we limited evidence of the bullwhip effect.

There are a few caveats of our study. First, while Amadeus data is the largest directly comparable firm-level data set for these countries, sample size differs substantially across countries, thus hazarding the external validity of the estimates obtained on this data to the whole economy. Second, our study does not control for the direction of trade. Since Central and Eastern European countries analyzed in this study are closely integrated with industrialized EU economies, mostly with Germany, it is possible that the shock was smaller than in the case of developing economies, studied in earlier research - indeed, economic downturn in Germany was relatively short lived and shallow, relative to other industrialized economies. Finally, these countries are characterized by relatively sound demand for own production, which means that adverse external shocks, if short lived, may be to some extent mitigated by domestic consumption.

\section{References}

Altomonte, C., Aquilante, T., Békés, G., Ottaviano, G. I., 2013. Internationalization and innovation of firms: evidence and policy. Economic Policy 28: 663-700.

Antràs, P., Chor, D., Fally, T., Hillberry, R., 2012. Measuring the upstreamness of production and trade flows. American Economic Review, 102: 412-416.

Antràs, P., Chor, D., 2013. Organizing the global value chain. Econometrica 81: 2127-2204. 
Baldwin, R., 2011. Trade and industrialisation after globalisation's 2nd unbundling: How building and joining a supply chain are different and why it matters. NBER Working Paper No. 17716, National Bureau of Economic Research

Baldwin, R., Venables, A. J., 2013. Spiders and snakes: offshoring and agglomeration in the global economy. Journal of International Economics, 90: 245-254.

Baldwin, R., Robert-Nicoud, F., 2014. Trade-in-goods and trade-in-tasks: An integrating framework. Journal of International Economics 92: 51-62.

Baldwin, R. E., Evenett, S., 2015. Value creation and trade in 21st century manufacturing. Journal of Regional Science, 55: 31-50.

Bems, R., Johnson, R. C., Yi, K. M., 2013. The Great Trade Collapse. Annual Review of Economics 5: 375-400.

Bloom, N., Draca, M., Van Reenen, J., 2016. Trade induced technical change? The impact of Chinese imports on innovation, IT and productivity. Review of Economic Studies, 83: 87-117.

Buono, I., Caffarelli, F. V., 2012. Trade Elasticity and Production Fragmentation. ETSG 2012, mimeo

Burda, M. C., Dluhosch, B., 2002. Cost competition, fragmentation, and globalization. Review of International Economics 10: 424-441.

Dietzenbacher, E., Los, B., Stehrer, R., Timmer, M., De Vries, G., 2013. The construction of world input-output tables in the WIOD project. Economic Systems Research 25: 71-98.

Egger, P. H., Erhardt, K., Lassmann, A., 2015. Productivity and R\&D as Drivers of Exports and Domestic Sales: Semi-parametric Evidence from French Firm-level Data. The World Economy 38: 1115-1129.

Fally, T., 2012. On the Fragmentation of Production in the US, University of ColoradoBoulder, mimeo.

Foster-McGregor, N., Poeschl, J., Stehrer, R., 2016. Offshoring and the Elasticity of Labour Demand. Open Economies Review 27: 513-540.

Guerrieri, P., Vergara Caffarelli, F. (2012). Trade openness and international fragmentation of production in the European Union: the new divide? Review of International Economics 20: 535-551.

Hagemejer, J., 2015. Productivity spillovers in the GVC. The case of Poland and the New EU Member States, WNE UW Working Papers No. 2015-42, University of Warsaw.

Hagemejer, J., Ghodsi, M., 2016. Up or down the value chain? The comparative analysis of the GVC position of the economies of the new EU Member States, WNE UW Working Paper No. 2016-23, University of Warsaw.

Hausmann, R., Hwang, J., Rodrik, D., 2007. What you export matters, Journal of Economic Growth 12: 1-25.

Hummels, D., Ishii, J., Yi, K.M., 2001. The Nature and Growth of Vertical Specialization in World Trade. Journal of International Economics 54: 75-96. 
Hurst, R., Buttle M., Sandars, J., 2010. The impact of the global economic slowdown on the value chain labor markets in Asia. In: Bauer, A. (ed.) Poverty and sustainable development in Asia: impacts and responses to the global economic crisis (pp. 113130), Mandaluyong City: Asian Development Bank.

Kalemli-Ozcan, S., Sorensen, B., Villegas-Sanchez, C., Volosovych, V., Yesiltas, S., 2015. How to construct nationally representative firm level data from the ORBIS global database NBER Working Paper No. 21558. National Bureau of Economic Research.

Milberg, W., Winkler, G., 2010. Trade crisis and recovery: restructuring global value chains. Policy Research Working Paper No.5294. The World Bank.

NBP, 2015, Quarterly Labor Market Review, National Bank of Poland

Sinha, A., 2010. Global Meltdown and Informality: An Economy-Wide Analysis for India Policy Research Brief, In: Bauer, A. (ed.) Poverty and sustainable development in Asia: impacts and responses to the global economic crisis (pp. 131-140), Mandaluyong City: Asian Development Bank.

Sturgeon, T., Kawakami, M., 2010. Global Value Chains in the Electronics Industry: Was the Crisis a Window of Opportunity for Developing Country. Policy Research Working Paper No. 5417. The World Bank.

Sturgeon, T., Van Biesebroeck, J., 2010. Effects of the crisis on the automotive industry in developing countries: a global value chain perspective. Policy Research Working Paper No. 5330. The World Bank.

Timmer, M. P., Dietzenbacher, E., Los, B., Stehrer, R., Vries, G. J., 2015. An illustrated user guide to the world input-output database: the case of global automotive production. Review of International Economics 23: 575-605.

Timmer, M. P., Inklaar, R., O’Mahony, M., van Ark, B., 2010. Economic growth in Europe: a comparative industry perspective. Cambridge University Press.

Wang, Z., Wei, S. J., Zhu, K., 2013. Quantifying International Production Sharing at the Bilateral and Sector Levels, NBER Working Paper No. 19677, National Bureau of Economic Research.

Zavacka, V., 2012. The bullwhip effect and the Great Trade Collapse. Working Paper No. 148. European Bank for Reconstruction and Development. 
Figure 1 Percentage of foreign firms in total employment: all firms and manufacturing
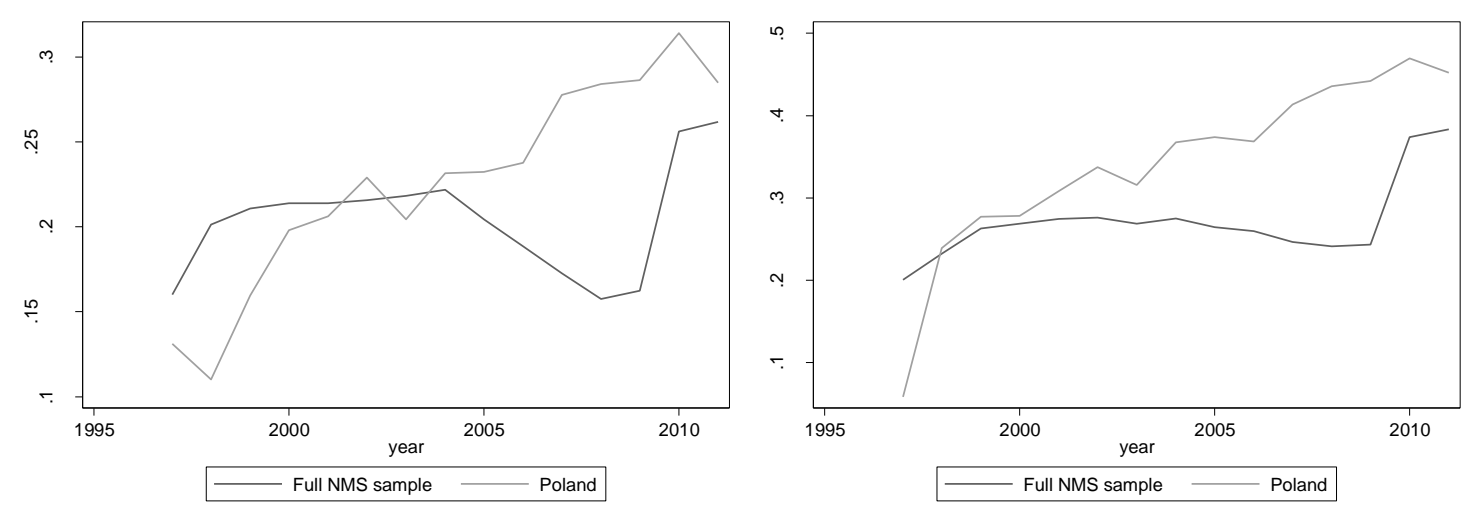

Note: foreign firms defined by any foreign ownership as coded in the originally reported ownership data. Non-weighted average. Full sample - left, manufacturing - right. Data: Amadeus

Figure 2 Openness indicators: share of exports in output (left), share of intermediate imports in output (right)
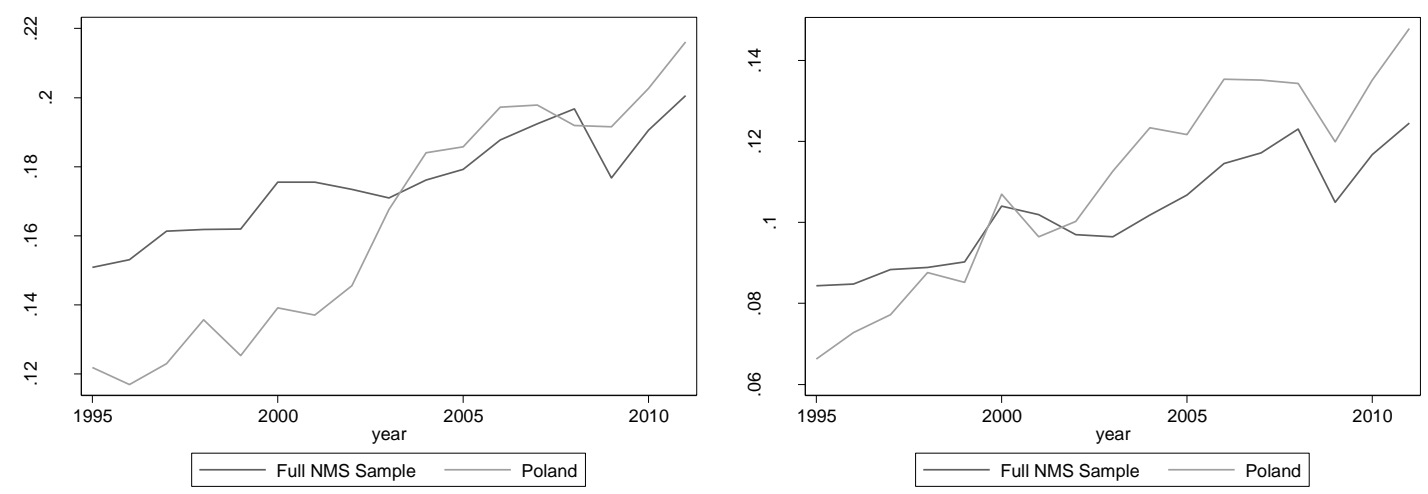

Note: Calculations based on WIOD. Note that the NMS indicators are computed at the region level and not averaged across countries. 
Figure 3 Estimated elasticity for job creation and job destruction across countries
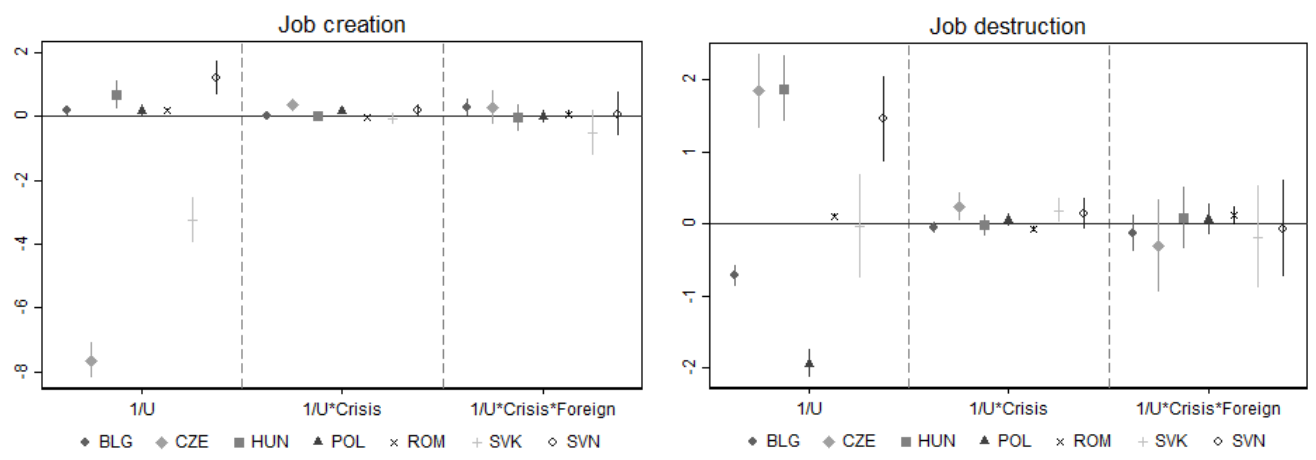

Note: estimates analogous to columns (3) and (4) in Table 2, obtained separately for the reported countries in the sample, detailed logs available upon request. Data: Amadeus 
Table 1 Summary statistics

\begin{tabular}{|c|c|c|c|c|c|c|c|c|}
\hline Variable & \multicolumn{4}{|c|}{ Poland -full sample } & \multicolumn{3}{|c|}{ NMS - full sample } & sd \\
\hline Employment & 87398 & 177.8 & 70.0 & 745.4 & 1334832 & 62.7 & 12.0 & 442.9 \\
\hline Employment growth & 87398 & 0.0 & 0.0 & 0.3 & 1334832 & 0.0 & 0.0 & 0.4 \\
\hline Job creation & 87398 & 0.0 & 0.0 & 0.2 & 1334832 & -0.1 & 0.0 & 0.3 \\
\hline Job destruction & 87398 & 0.1 & 0.0 & 0.2 & 1334832 & 0.1 & 0.0 & 0.3 \\
\hline Unit labour cost & 87381 & 0.2 & 0.1 & 3.1 & 1334471 & 0.2 & 0.1 & 1.4 \\
\hline Value added & 87398 & 20070.5 & 6942.0 & 85261.2 & 1334832 & 4987.3 & 572.0 & 41753.6 \\
\hline Investment rate & 87398 & 0.3 & 0.0 & 1.4 & 1334832 & 0.4 & 0.0 & 2.4 \\
\hline $\begin{array}{l}\text { Intermediate imports } \\
\text { /output }\end{array}$ & 87398 & 0.1 & 0.1 & 0.1 & 1334832 & 0.1 & 0.1 & 0.1 \\
\hline 1 / Upstreamness & 87398 & 0.5 & 0.4 & 0.1 & 1334832 & 0.5 & 0.5 & 0.1 \\
\hline Export share & 87398 & 0.2 & 0.1 & 0.2 & 1334832 & 0.2 & 0.2 & 0.2 \\
\hline $\begin{array}{l}\text { Intermediate exports / } \\
\text { exports }\end{array}$ & 87398 & 0.1 & 0.0 & 0.1 & 1334832 & 0.1 & 0.1 & 0.1 \\
\hline variable & $\mathrm{N}$ & \multicolumn{2}{|c|}{ Poland - manufacturing } & sd & \multicolumn{3}{|c|}{ NMS - manufacturing } & sd \\
\hline Employment & 26879 & 205.1 & 108.0 & 339.2 & 298819 & 116.9 & 31.0 & 338.3 \\
\hline Employment growth & 26879 & 0.0 & 0.0 & 0.2 & 298819 & 0.0 & 0.0 & 0.4 \\
\hline Job creation & 26879 & 0.0 & 0.0 & 0.1 & 298819 & -0.1 & 0.0 & 0.3 \\
\hline Job destruction & 26879 & 0.1 & 0.0 & 0.2 & 298819 & 0.1 & 0.0 & 0.3 \\
\hline Unit labour cost & 26877 & 0.2 & 0.1 & 0.1 & 298787 & 0.2 & 0.2 & 0.9 \\
\hline Value added & 26879 & 22565.6 & 7830.0 & 66411.9 & 298819 & 7481.9 & 957.0 & 51997.6 \\
\hline Investment rate & 26879 & 0.2 & 0.0 & 1.7 & 298819 & 0.3 & 0.0 & 1.7 \\
\hline $\begin{array}{l}\text { Intermediate imports } \\
\text { /output }\end{array}$ & 26879 & 0.2 & 0.2 & 0.1 & 298819 & 0.2 & 0.2 & 0.1 \\
\hline 1 / Upstreamness & 26879 & 0.5 & 0.4 & 0.1 & 298819 & 0.5 & 0.4 & 0.2 \\
\hline Export share & 26879 & 0.5 & 0.5 & 0.2 & 298819 & 0.4 & 0.4 & 0.3 \\
\hline $\begin{array}{l}\text { Intermediate exports / } \\
\text { exports }\end{array}$ & 26879 & 0.3 & 0.3 & 0.1 & 298819 & 0.2 & 0.2 & 0.2 \\
\hline
\end{tabular}

Note: foreign firms defined by any foreign ownership as coded in the originally reported ownership data. Sample not weighed. Data: Amadeus 
Table2 Estimating labor demand in Poland

\begin{tabular}{|c|c|c|c|c|c|c|c|c|}
\hline \multirow[b]{2}{*}{ VARIABLES } & \multicolumn{4}{|c|}{ All firms } & \multicolumn{4}{|c|}{ Manufacturing } \\
\hline & Level & growth & JC & JD & Level & Growth & $\mathrm{JC}$ & JD \\
\hline & (1) & (2) & (3) & (4) & (5) & (6) & (7) & (8) \\
\hline & AREG & AREG & TOBIT & TOBIT & AREG & AREG & TOBIT & TOBIT \\
\hline \multirow[t]{2}{*}{ Labor cost } & $-0.65^{* * *}$ & $-0.49^{* * *}$ & $-0.71^{* * *}$ & $-0.63^{* * *}$ & $-0.78^{* * *}$ & $-0.48^{* * *}$ & $-0.71^{* * *}$ & $-0.56^{* * *}$ \\
\hline & $(0.05)$ & $(0.02)$ & $(0.00)$ & $(0.01)$ & $(0.07)$ & $(0.03)$ & $(0.01)$ & $(0.01)$ \\
\hline \multirow[t]{2}{*}{ Output } & $0.77^{* * *}$ & $0.34^{* * *}$ & $0.52^{* * *}$ & $0.47^{* * *}$ & $0.80^{* * *}$ & $0.36^{* * *}$ & $0.57^{* * *}$ & $0.44^{* * *}$ \\
\hline & $(0.03)$ & $(0.02)$ & $(0.00)$ & $(0.01)$ & $(0.01)$ & $(0.02)$ & $(0.01)$ & $(0.01)$ \\
\hline \multirow[t]{2}{*}{ Investment rate } & $-0.20^{* * *}$ & $0.06^{* * *}$ & $0.11^{* * *}$ & $0.07^{* * *}$ & $-0.28^{* * *}$ & $0.07^{* * *}$ & $0.13^{* * *}$ & $0.09 * * *$ \\
\hline & $(0.05)$ & $(0.00)$ & $(0.00)$ & $(0.01)$ & $(0.03)$ & $(0.01)$ & $(0.01)$ & $(0.01)$ \\
\hline \multirow[t]{2}{*}{ 1/Upstreamness $(1 / U)$} & $1.91^{* *}$ & $-0.44^{* * *}$ & $0.18^{*}$ & $-1.96^{* * *}$ & 0.05 & $-0.03^{* *}$ & $-0.09 * * *$ & -0.02 \\
\hline & $(0.73)$ & $(0.07)$ & $(0.10)$ & $(0.10)$ & $(0.03)$ & $(0.01)$ & $(0.03)$ & $(0.03)$ \\
\hline \multirow[t]{2}{*}{ Intermediate inputs / output } & $-2.64 * * *$ & $0.21^{* *}$ & $-0.61^{* * *}$ & $2.52^{* * *}$ & $-1.50 * * *$ & 0.12 & $-0.45^{* * *}$ & $1.49 * * *$ \\
\hline & $(0.73)$ & $(0.10)$ & $(0.13)$ & $(0.13)$ & $(0.49)$ & $(0.12)$ & $(0.15)$ & $(0.14)$ \\
\hline \multirow[t]{2}{*}{ Intermediate exports / exports } & 0.12 & $0.32^{* *}$ & $0.91^{* * *}$ & -0.19 & 0.03 & $0.21^{*}$ & $0.57^{* * *}$ & -0.11 \\
\hline & $(0.52)$ & $(0.12)$ & $(0.14)$ & $(0.14)$ & $(0.55)$ & $(0.11)$ & $(0.14)$ & $(0.14)$ \\
\hline \multirow[t]{2}{*}{ Export share in sales } & -0.34 & $-0.19 * *$ & $-0.60^{* * *}$ & $0.26^{* * *}$ & -0.37 & -0.09 & $-0.38^{* * *}$ & $0.38^{* * *}$ \\
\hline & $(0.34)$ & $(0.07)$ & $(0.09)$ & $(0.09)$ & $(0.32)$ & $(0.05)$ & $(0.08)$ & $(0.08)$ \\
\hline \multirow[t]{2}{*}{ Global financial crisis (GFC) } & $0.16^{*}$ & $-0.04^{* * *}$ & $-0.11^{* * *}$ & $-0.06^{* * *}$ & 0.05 & $-0.03^{* *}$ & $-0.09^{* * *}$ & -0.02 \\
\hline & $(0.08)$ & $(0.01)$ & $(0.02)$ & $(0.02)$ & $(0.03)$ & $(0.01)$ & $(0.03)$ & $(0.03)$ \\
\hline \multirow[t]{2}{*}{ Foreign ownership (FO) } & -0.02 & 0.00 & 0.04 & $0.05^{* *}$ & -0.07 & 0.05 & $0.15^{* *}$ & -0.06 \\
\hline & $(0.18)$ & $(0.01)$ & $(0.02)$ & $(0.02)$ & $(0.08)$ & $(0.03)$ & $(0.07)$ & $(0.06)$ \\
\hline \multirow[t]{2}{*}{$\mathrm{GFC} \# 1 / \mathrm{U}$} & $-0.37^{* *}$ & $0.06^{* * *}$ & $0.19^{* * *}$ & $0.06^{*}$ & $-0.31^{* * *}$ & 0.01 & $0.06^{* *}$ & -0.00 \\
\hline & $(0.14)$ & $(0.02)$ & $(0.04)$ & $(0.04)$ & $(0.06)$ & $(0.02)$ & $(0.02)$ & $(0.03)$ \\
\hline \multirow[t]{2}{*}{ FO \# 1/U } & -0.08 & 0.02 & 0.02 & -0.00 & $0.43^{* *}$ & 0.01 & -0.05 & 0.08 \\
\hline & $(0.33)$ & $(0.03)$ & $(0.05)$ & $(0.05)$ & $(0.16)$ & $(0.03)$ & $(0.05)$ & $(0.06)$ \\
\hline \multirow[t]{2}{*}{ GFC \# FO } & -0.08 & 0.00 & 0.01 & -0.07 & 0.08 & -0.01 & -0.01 & -0.07 \\
\hline & $(0.10)$ & $(0.03)$ & $(0.05)$ & $(0.05)$ & $(0.08)$ & $(0.04)$ & $(0.06)$ & $(0.06)$ \\
\hline \multirow[t]{2}{*}{ GFC \# FO \# 1/U } & $0.36^{*}$ & -0.03 & -0.02 & 0.01 & -0.04 & -0.02 & -0.00 & 0.04 \\
\hline & $(0.21)$ & $(0.06)$ & $(0.10)$ & $(0.10)$ & $(0.18)$ & $(0.08)$ & $(0.13)$ & $(0.13)$ \\
\hline No of observations & 87,406 & 87,398 & 87,398 & 87,398 & 26,879 & 26,879 & 26,879 & 26,879 \\
\hline R-squared & 0.72 & 0.43 & & & 0.73 & 0.42 & & \\
\hline
\end{tabular}

Note: constant included but not reported, all linear specifications with firm-level fixed effects with standard errors clustered at sector level, tobit models estimated with standard errors clustered at sector level. Specifications in columns (1) and (4) in logs, remainder of the table in first differences (except for investment rate, because it is measured as flow). Standard errors reported in parentheses, ${ }^{* * *} \mathrm{p}<0.01,{ }^{* *} \mathrm{p}<0.05,{ }^{*} \mathrm{p}<0.1$ 